\title{
Honey bee stop-signal production: temporal distribution and effect of feeder crowding*
}

\author{
Constantine W. LAU ${ }^{1}$, James C. NIEH ${ }^{1,2}$ \\ ${ }^{1}$ University of California San Diego, Section of Ecology, Behavior, and Evolution, \\ Division of Biological Sciences, La Jolla, CA 92093, USA \\ ${ }^{2}$ UCSD, MC0116, 9500 Gilman Drive, La Jolla, CA 92093-0116, USA
}

Received 25 March 2009 - Revised 11 June 2009 - Accepted 18 June 2009

\begin{abstract}
The honey bee stop-signal may decrease recruitment by causing waggle dancers to cease dancing when food patch conditions deteriorate. However, little is known about how signaling may change during the time a signaler is inside the nest and what triggers signal production. All previous feeder studies have used crowded feeders to stimulate stop-signal production. We focused on individual foragers and found that bees returning from uncrowded feeders also produced stop-signals. The number of signals produced by these foragers was roughly proportional to the duration of their stay in the nest. Foragers significantly decreased the rate of signal production throughout their nest stay, potentially reflecting a decrease in signaling motivation with increased time inside the nest. There is a slight trend for signal pulse duration to increase and fundamental frequency to decrease throughout a signaler's nest stay. We examined the effect of crowded feeder conditions by training 20 foragers to a feeder and following focal forager behavior before and after reducing the number of feeding spots. This manipulation increased feeding wait time from $0 \mathrm{~s}$ to $409.4 \pm 264.3 \mathrm{~s}$ without significantly increasing colony nectar intake. Our treatment did not change signal production by focal foragers but significantly doubled the number of stop-signals that focal foragers received inside the nest. At least 38\% of these received signals came from foragers visiting the same feeder. Thus, the colony produces stop-signals at a baseline level that can be elevated in response to crowded foraging conditions.
\end{abstract}

stop-signal / brief piping signal / foraging / negative feedback / crowding

\section{INTRODUCTION}

Vibrational signals play an important role in social insects, helping to tune collective decision-making and coordinate tasks such as house-hunting and foraging (Schneider and Lewis, 2004). Such vibrational signals generally provide positive feedback. For example, Hölldobler and Wilson (1990) reported that two ant species in the genus Aphaenogaster stridulate and produce alarm pheromone to recruit nestmates to help carry large prey items. Worker leaf-cutting ants (Atta cephalotes)

Corresponding author: J.C. Nieh, jnieh@ucsd.edu

* Manuscript editor: Stan Schneider stridulate while cutting leaves and thereby recruit nestmates to assist in the cutting (Roces et al., 1993). Successful stingless bee foragers, Melipona seminigra, generate thoracic vibrations that are transmitted to food receivers during trophallaxis and may elicit recruitment (Hrncir et al., 2006). Bumble bees, Bombus impatiens, returning from a rich food source can move excitedly inside the nest, contacting nestmates who then have an increased probability of exiting the nest to forage (Renner and Nieh, 2008). In honey bees, the vibratory "shaking signal" increases the activity of recipients and alters their responsiveness to different stimuli (Schneider et al., 1986; Seeley et al., 1998). 
In contrast, the honey bee "stop-signal" is a vibrational signal that evidently provides negative feedback, decreasing recruitment for overexploited food sources by inhibiting recruitment (Kirchner, 1993; Nieh, 1993; Pastor and Seeley, 2005). This signal has also been called the "brief piping signal", because the signal production mechanism and dominant frequency is similar to other worker piping signals (Seeley and Tautz, 2001; Thom et al., 2003). The stop-signal consists of the sender butting her head into a recipient while producing a relatively brief vibrational signal lasting approximately $150 \mathrm{~ms}$ (Kirchner, 1993) at around $380 \mathrm{~Hz}$ (Michelsen et al., 1986; Thom et al., 2003). Stop-signalers primarily direct their signals at waggle dancers (Nieh, 1993). This may have led the signal to be originally called a "begging call," as the signaler was believed to obtain a food sample from the signal receiver (Esch, 1964; von Frisch, 1946). However, researchers have subsequently found no evidence that the stop-signaler receives food from the signal receiver as a result of producing a stop-signal (Nieh, 1993; Pastor and Seeley, 2005).

We use the term "stop-signal" to distinguish this signal from other forms of worker piping because experiments show that the stop-signal can cause waggle dancers to stop dancing and leave the nest, thereby reducing recruitment. Playbacks of the stop-signal (artificial vibrations of the comb with a vibrational exciter connected to the substrate) reduced the waggle dance durations by $59 \%$. At the same time, playbacks reduced recruitment by $60 \%$ (Kirchner, 1993). Nieh (1993) directly contacted waggle dancers with a vibrating rod playing back natural and synthesized stopsignals and also found that playbacks increase the probability of waggle dancer departure. These studies used honey bees trained to artificial feeders. Pastor and Seeley (2005) subsequently studied bees foraging at natural floral resources and found that waggle dancing recipients of natural stop-signals ceased dancing significantly more often than expected by chance alone.

Why would honey bees need to inhibit foraging? Perhaps one key to this mystery lies in the strong link between stop-signal produc- tion and tremble dancing. From $85 \%$ to $95 \%$ of bees producing stop-signals do so while tremble dancing (Nieh, 1993; Thom et al., 2003). Foragers perform tremble dances for rich food sources when they experience long unloading times upon their return to the nest, and tremble dancing results in the recruitment of additional food storage bees, thereby reducing the food intake bottleneck (Seeley, 1992). Thom (2003) showed that foragers returning from a rich food source will also produce tremble dances when it becomes crowded, and Thom et al. (2003) suggested that stop-signals may enhance the tremble dance's effectiveness at recruiting food storage bees. Thus, while the tremble dance recruits additional food unloaders, the stop-signal could reduce recruitment until the bottleneck is relieved.

In general, a crowded feeder leads to a large increase in stop-signal production (Kirchner, 1993; Nieh 1993; Thom et al., 2003). Allowing a large number of foragers to build up at a feeder has several effects such as increasing forager wait time (the time bees must wait after arriving at the food source in order to access the nectar) and colony nectar intake. Thom et al. (2003) demonstrated that restricting the number of feeding slots (and therefore increasing feeder wait time without increasing colony nectar intake) can increase tremble dancing. However, the effect of feeder wait time on stop-signal production is not known.

Stop-signalers can also produce multiple signals inside the nest (Nieh, 1993; Thom et al., 2003), but it is not known if signals change throughout an individual's performance. If the signaler is communicating an adverse change in foraging conditions, does she produce the most signals immediately upon returning to the nest, or does her signaling motivation (signaling rate or duty cycle) change (Bradbury and Vehrencamp, 1998) the longer she spends inside the nest? These basic questions remain unanswered.

Our goal was to learn more about the conditions that lead to stop-signal production and to determine if stop-signals change throughout an individual's time inside the nest to reflect potential changes in signaler motivation. Unlike other studies (Kirchner, 1993; Nieh, 1993; Pastor and Seeley, 2005), we focused 
on individual signalers, and followed focal foragers for their entire time inside the nest.

\section{METHODS AND MATERIALS}

\subsection{Colonies and study sites}

We sequentially used two honey bee colonies (Apis mellifera), each containing approximately 3000-4000 workers housed in an observation hive $(56.5 \times 78.7 \mathrm{~cm})$ containing three standard $22.9 \times$ $45.7 \mathrm{~cm}$ American Langstroth combs. We covered two sides of the hive with clear polyethylene film (for observation) and wood doors (closed during non-observation periods). We trained foragers to a feeder which had a $2.5 \mathrm{~cm}$ diameter disk of filter paper scented with $20 \mu \mathrm{L}$ lemon extracts (McCormick\&Co., Hunt Valley, MD) placed on the top of the feeder atop a $1 \mathrm{~m}$ high tripod. The feeder consisted of unscented 2.5 M sucrose solution in an inverted glass jar $(5.5 \mathrm{~cm}$ diameter $\times 4.9 \mathrm{~cm})$ on a clear plastic plate $(10 \mathrm{~cm}$ diameter $)$ with 60 grooves radiating from the plate center (von Frisch, 1967). We allowed a fixed number of bees to visit the feeder and captured excess bees with a tube aspirator $(3 \mathrm{~cm}$ diameter $\times 20.4 \mathrm{~cm})$. We uniquely marked all foragers who landed on the feeder for more than $1 \mathrm{~s}$ (the minimum time required for marking) with acrylic paints and later verified that they came from the focal colony by checking to see if they returned to the focal colony. No bees from other colonies were detected during our experiments. We conducted experiments from 1000 to 1500 .

During experiments, we removed the wood door and plastic film from one side of the colony to videotape and record sounds. Foragers entered through the $0.5 \mathrm{~m}$ long nest entrance tube, moved up into the comb region and then exited either through the nest entrance or by flying from the exposed comb. A performance began when a bee entered the comb region of the nest and ended when the bee exited the nest. We videotaped (Panasonic, Secaucus, NJ, model PV-DV402D) the entire performance of a focal forager randomly selected from marked bees visiting the feeder. We analyzed the digital video with iMovie (v5.0.2) software. We defined an unloading event as the first trophallaxis between the focal forager and a nestmate that was longer than $4 \mathrm{~s}$ (Farina and Wainselboim, 2001). Based upon the methodology of Seeley (1992), we therefore define the unloading wait time as the duration of time between the forager's entry into the nest and her first unloading event. We recorded sounds with a microphone (Radio Shack, Fort Worth, TX, model: 33$3013)$ attached at the end of plastic rod $(24.6 \mathrm{~cm}$ long) held approximately $1 \mathrm{~cm}$ above the thorax of the focal bee by a tracking observer. This microphone has a relatively flat frequency response from 30-10 $000 \mathrm{~Hz}$ (calibrated with a Brüel and Kjaer Type 4192 microphone, Norcross, GA).

\subsection{Experiment 1: signal changes throughout a performance}

To determine how stop-signals are distributed within a performance, we used colony $\mathrm{A}$ at the UC Elliott Natural Reserve in San Diego, CA (N32 $53.597^{\prime}$ and $\mathrm{W} 117^{\circ} 06.435^{\prime}$, site 1) from June to August 2006. We kept the colony under a $3 \times$ $3 \mathrm{~m}$ canopy shelter. During this time, natural food sources were abundant, and foragers could only be reliably trained to a $2.5 \mathrm{M}$ feeder $8 \mathrm{~m}$ from the nest. To eliminate potential crowding, we trained only five bees at a time to the feeder, which could accommodate over 40 bees. Because feeding slots were not limited, all bees could be marked with paints as soon as they landed. Excess bees (above five, as censused each $15 \mathrm{~min}$ ) were captured and held in aspirators until the end of the day when they were released. We recorded the performance of each bee only once, and then captured her with an aspirator. We released these "used" bees at the end of each day and recaptured all such bees on subsequent days if they returned to the feeder. As necessary, we trained new bees to the feeder or allowed new recruits to feed. We measured the temporal distribution of signals within each performance (standardizing times by dividing the time of signal production by total performance duration). On a group of randomly selected performances, we measured the duration and fundamental frequency of each stop-signal with RavenPro v1.3).

\subsection{Experiment 2: feeder crowding}

We used Colony A from September to November 2006 and Colony B from April to May 2007 at the UC San Diego Biological Field Station $\left(\mathrm{N} 32^{\circ} 53.127^{\prime}\right.$ and $\mathrm{W} 117^{\circ} 13.785^{\prime}$, site 2$)$. We trained foragers to a feeder placed at $70 \mathrm{~m}$ away from the nest, and used a pairwise design to minimize the effects of signaling differences between individual bees, time, date, and weather. We trained 
20 foragers to the feeder and video recorded each focal forager for two consecutive visits inside the nest (Before and Treatment phases). In the Before phase, bees did not wait for feeder access ( $0 \mathrm{~s}$ wait time) and began feeding as soon as they landed. Once the focal forager was inside the nest for her Before phase performance, we exchanged the multigrooved Before feeder with the Treatment feeder (one that had only a single feeding groove accessible through a hole in a thin wax membrane). The membrane allowed us to limit foraging to a single bee at a time. This crowding method does not increase nectar flow back into the colony.

When the focal forager returned to the feeder, we measured feeder wait time (the amount of time she waited before being able to feed). Foragers typically waited by flying above the feeding spot and landing for short periods next to the feeding bee. Foragers therefore experienced increased wait times and greater physical proximity (crowding) in the Treatment phase. We never observed aggression among waiting bees.

In the Before phase, the feeder was uncrowded and thus we could mark all foragers landing on the feeder with individual paint marks, censusing each 15 min to ensure that 20 bees visited and capturing excess foragers and recruits (after painting) with aspirators. In the Treatment phase, we could only paint bees that landed for at least $1 \mathrm{~s}$. Thus, there were some unmarked bees that hovered around the feeder without landing or which landed for a fraction of a second and could not be painted. These unmarked bees were likely recruits who did not yet know how to feed from the feeder.

\subsection{Statistical methods}

We analyzed all data with JMP IN (v4.0.4). All data met criteria for normality (residual analysis) and thus we used parametric statistics. We tested the temporal distribution of stop-signals over all performances using a 2-tailed t-test. We avoided pseudoreplication by calculating the average standardized time of signal production per bee performance and then testing the mean of these averages (each value representing a different bee) against an expected mean of 0.5 (mean signaling time of $0.5=$ the middle of her stay in the nest). We used ANOVA and 2-tailed paired t-tests to compare the behavior of the same individuals before and after the crowding treatment. We report averages as mean \pm 1 standard deviation.

\section{RESULTS}

\subsection{Experiment 1: signal changes throughout a performance}

In this experiment, foragers did not need to wait for feeder access and did not experience feeder crowding. Nonetheless, some foragers (30\% out of 143 different foragers) produced stop-signals. In our observations, $90 \%$ of bees producing stop-signals also tremble danced and $22 \%$ of all focal bees produced tremble dances. In nearly all cases, tremble dances began as soon as the forager entered the nest and persisted until she departed. On average, foragers waited $12.2 \pm 5.2 \mathrm{~s}$ before unloading their food inside the nest.

Foragers who spend longer time periods inside the nest produced more stop-signals (Fig. 1a, $R^{2}=0.59, F_{1,41}=57.9, P<0.0001$, slope $=1.47$ signals $/ \mathrm{min}, N=43$ bees). Foragers did not produce stop-signals uniformly throughout their time inside the nest. Stopsignal production decreased throughout a signaler's nest stay (Fig. 1b). The distribution of the average standardized time of signal production also decreases throughout a signaler's nest stay and is significantly less than 0.5 (2tailed $t$-test, $t_{42}=-2.9, P=0.006$, Fig. $\left.1 \mathrm{c}\right)$.

We randomly selected 33 performances and measured temporal and frequency characteristics of all signals $(N=274)$. Stop-signals had an average duration of $0.17 \pm 0.05 \mathrm{~s}$ and an average fundamental frequency of $328.3 \pm 58.8 \mathrm{~Hz}$. There is a slight trend for signal duration $\left(R^{2}=0.05\right.$, slope $=$ $0.03)$ and fundamental frequency $\left(R^{2}=0.02\right.$, slope $=-23.5)$ to change with the standardized time of signal production (increased duration: $F_{1,272}=13.2, P=0.0003$; decreased frequency $F_{1,272}=4.6, P=0.032$ ). This trend accounts for a $21 \%$ increase in duration and a $24 \%$ decrease in frequency when regression estimates for the end and beginning of each performance are compared.

\subsection{Experiment 2: feeder crowding}

There is no significant Treatment effect on unloading wait times (time foragers waited 

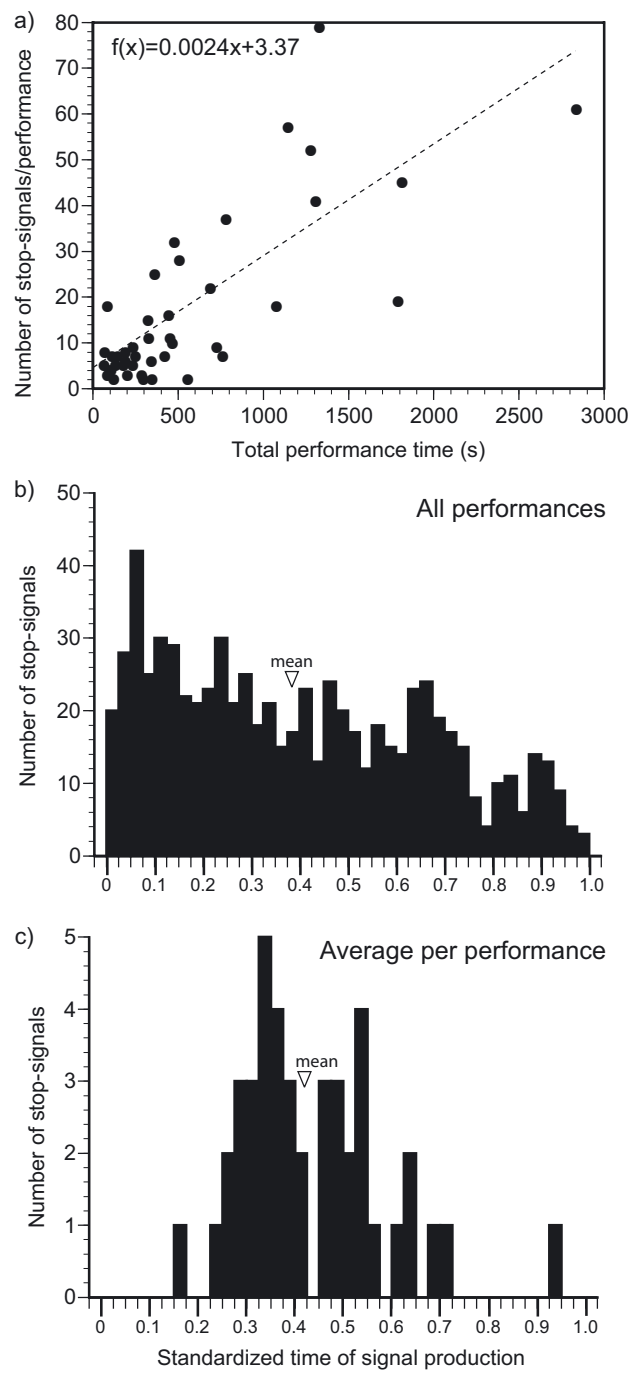

Figure 1. Temporal distribution of stop-signals $(N=43$ bees, average performance length $=$ $550.5 \pm 579.3 \mathrm{~s}$, total analysis time $=6.58 \mathrm{hrs}$ ). We show the standardized time of signal production, which is calculated as the time of signal production divided by total performance time (total time that a forager spent inside the nest after returning from the feeder). (a) Number of signals vs. performance duration. Dashed linear regression line shown. (b) Histogram of standardized time of signal production in all performances (725 signals, mean $=0.397 \pm 0.268$ ). (c) Histogram of the average standardized time of signal production per performance. The number of signals is higher towards the beginning than the end of each performance $($ mean $=0.434 \pm 0.150)$.

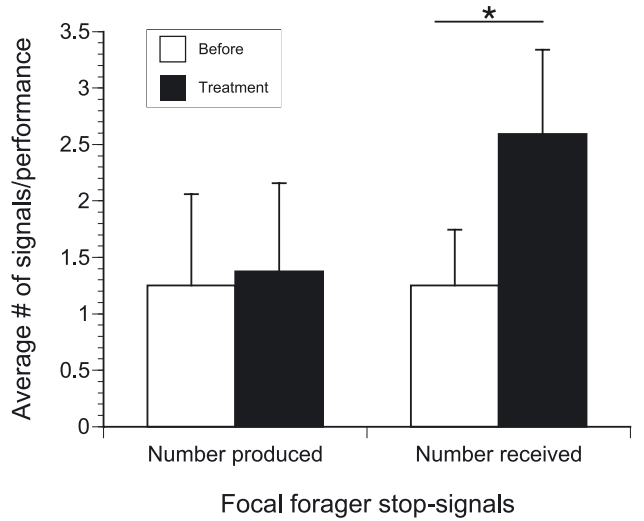

Figure 2. Effect of feeder crowding on the number of stop-signals produced and received by focal foragers ( $N=32$ bees). Standard error bars are shown and significant differences $(P=0.01)$ are marked with a horizontal line and asterisk.

inside the nest before unloading their food). We find no significant difference between the Before and Treatment phases in performance times (overall $173.4 \pm 214.4 \mathrm{~s}$, paired $t$-test, $\left.t_{31}=1.86, P=0.07\right)$ or unloading wait times (overall $13.2 \pm 15.8 \mathrm{~s}$, paired $t$-test, $t_{31}=$ $-0.51, P=0.62$ ). In total, $15.6 \%$ of focal foragers tremble danced in the Before phase and $21.9 \%$ in the Treatment phase $(N=32)$. Overall, $75 \%$ of bees producing stop-signals did so while tremble dancing (Before and Treatment phases combined).

However, there is a significant Treatment effect on feeder wait times (time foragers waited at the feeder to access food). Focal foragers waited significantly longer (paired $t$-test, $\left.t_{31}=-8.76, P<0.0001\right)$ during the Treatment phase $(409.4 \pm 264.3 \mathrm{~s})$ as compared to the Before phase $(0 \pm 0 \mathrm{~s})$. Focal foragers did not produce significantly more signals in the Treatment phase $(1.25 \pm 4.59$ signals/performance $)$ as compared to the Before phase $(1.38 \pm 4.42$ signals/performance, paired $t$-test, $t_{31}=0.64$, $P=0.53$, Fig. 2). In the Treatment phase, there is no significant effect of feeder wait time on the number of stop-signals produced or received by focal foragers $\left(F_{1,30} \leqslant 1.01\right.$, $P \geqslant 0.32$ ).

Focal foragers received significantly more stop-signals (paired $t$-test, $t_{31}=2.64, P=$ $0.01)$ during the Treatment phase $(2.6 \pm 4.2)$ 
as compared to the Before phase $(1.3 \pm 2.8$ signals, Fig. 2). Foragers received, on average, $100 \%$ more stop-signals after returning from a crowded feeder as compared to a feeder at which they did not need to wait. Over $38 \%$ of received signals (out of 83 signals) came from foragers that we were able to mark and therefore were visiting the crowded feeder.

\section{DISCUSSION}

Thus, foragers trained to a rich food source at which they could feed without waiting or experiencing crowding, can produce stopsignals. Foragers produced significantly more stop-signals if they spent more time inside the nest (regression slope $=1.47$ signals $/ \mathrm{min}$, Fig. 1a), and the rate of signal production decreased over time (Fig. 1b, c). When we generated crowded feeding conditions by restricting feeder access and therefore causing bees to wait $409.4 \pm 264.3 \mathrm{~s}$ before feeding, the number of signals received by focal foragers doubled.

\subsection{Signal changes throughout a performance}

We measured an average stop-signal duration of $0.17 \pm 0.05 \mathrm{~s}$ and frequency of $328 \pm$ $59 \mathrm{~Hz}$, values within ranges reported in other studies $(0.10 \mathrm{~s}, 320 \mathrm{~Hz}$, Michelsen et al., 1986; 0.14 s, 350-450 Hz, Kirchner, 1993; 0.23 s, 270-540 Hz, Thom et al., 2003). The decline in the rate of signal production throughout a performance may reflect a decrease in signaling motivation. There is also a slight tendency for signal pulse duration to increase and fundamental frequency to decrease with increasing time inside the nest. We cannot explain why signal durations slightly increased throughout a performance. However, the slight change in fundamental frequency may result from the positive correlation, within limits, between frequency and insect body temperature (Ewing, 1989). Honey bees returning from a rich nectar source typically have elevated thoracic temperatures, which can gradually decrease throughout their stay in the nest (Stabentheiner, 1996; Stabentheiner et al., 1995). Decreased signaler body temperature should result in a decreased fundamental frequency.

\subsection{Feeder crowding experiment}

Focal foragers received more signals during the Treatment phase than the Before phase (Fig. 2), although we were not able to detect an increase in focal forager signal production during the Treatment phase. One possible explanation for the increase in received signals is that crowding caused some foragers to abandon the feeder and return to the nest. Foragers visiting the Treatment phase feeder produced at least $38 \%$ of signals received by focal foragers. A potentially higher fraction of the received signals could have come from foragers visiting the same feeder. However, we were unable to mark all of the bees visiting the feeder because many hovered around the feeder or landed only for a fraction of the second.

If more feeder-foragers returned to the nest during the Treatment phase than the Before phase, the number of stop-signal producers would be elevated, along with the number of signals received by focal foragers. We were unable to accurately census bees that flew around the feeder but did not land, and there were many of these in the Treatment phase. Because we focused on following an individual focal forager, we do not have data on how many trained foragers were inside the nest at any given time. Thus, feeder crowding may have increased the number of foragers inside the nest, a colony-wide effect that could increase the number of received signals.

\subsection{Tremble dancing}

Most stop-signalers were also tremble dancers and tremble danced throughout their time inside the nest. Thus, the observed stopsignal trends (temporal distribution, signal duration, and frequency) are also associated with the increasingly long tremble dancing bouts. Seeley (1992) elicited tremble dancing when 
he increased unloading wait times from $15 \mathrm{~s}$ to $35-40 \mathrm{~s}$ by increasing colony nectar intake. In our experiments, it is unclear why some foragers $(16 \%$ and $22 \%$ for colonies A and B) performed tremble dances despite relatively low unloading wait times (on average 12.2-13.2 s). Thom (2003) reported that tremble dancing can be triggered by feeder crowding, even when unloading wait times are short. However, the feeder was not crowded in experiment 1 or during the Before phase of experiment 2 . We therefore cannot explain why $16-22 \%$ of focal foragers tremble danced in these experiments. However, there may be a basal rate of tremble dancing that is influenced by natural colony or habitat-based variation.

\subsection{Natural context}

Bees can produce stop-signals after visiting natural food sources (Pastor and Seeley, 2005). If recruitment results in bees occupying most flowers in a patch, forager search time within the patch could increase. However, crowding is probably uncommon for floral resources. Crowding could also occur when honey bee foragers raid another colony for stored food (Couvillon et al., 2008; Seeley, 1985; Winston, 1987). An artificial feeder that provides ad libitum food at high sucrose concentration $(2.5 \mathrm{M})$ at a specific spatial point is, in these respects, more similar to a honey bee colony being raided than a floral patch. Future studies focusing on intraspecific competition and stop-signaling would therefore be useful.

Some data suggest that stop-signals can provide negative feedback that reduces waggle dancing (Kirchner, 1993; Nieh, 1993; Thom et al., 2003). It is therefore interesting and puzzling that stop-signals are also produced in the absence of obvious reasons for reducing foraging (experiment 1). Stop-signals can alter the probability of waggle dancers leaving the nest, but dancers do not show a strong, immediate response to a stop-signal (Nieh, 1993; Pastor and Seeley, 2005). This is characteristic of modulatory signals, which are produced in a variety of contexts and are characterized by slightly shifting the probability of receiver behaviors, depending upon receiver response thresholds (Hölldobler, 1999). Like other honey bee vibrational signals such as the shaking signal (also known as the vibration signal, Schneider and Lewis, 2004), the stopsignal may play a modulatory role and thus be present at baseline levels that allow receivers to collect and integrate information about food patch conditions from multiple signalers. Depending upon receiver response thresholds, we suggest that stop-signals do not exert a strong colony-wide effect until signaling levels are elevated. Such a colony-wide effect would therefore arise as an emergent property of multiple independent actors signaling and receiving information about food patch conditions, potentially increasing the accuracy of information exchange (Bonabeau et al., 1999).

\section{ACKNOWLEDGEMENTS}

We are greatly indebted to many wonderful field assistants and diligent data analyzers: Nicholas Huyuh, Kim Tong, Andrea Ross, Reena GutierrezTabita, Ashley Spooner, Lacey Lavigna, Danny Le, Amir Saadatisohi, Randy Yu, Tobin Hammer, Omid Zebarjadi, Sarah Horng and Michelle Scott. We would also like to thank Brian Johnson, David Holway, Kirk Visscher, and the anonymous reviewers whose comments have significantly improved our manuscript. This research was partially supported by NSF IBN 0316697, NSF IBN 0545856, and the ORBS (Opportunities for Research in the Behavioral Sciences) Program.

Production d'un signal d'arrêt chez l'abeille : distribution dans le temps et effet d'un afflux de butineuses sur le nourrisseur.

Apis mellifera / signal d'arrêt / "piping signal" bref / approvisionnement / réaction négative

Zusammenfassung - Produktion eines Stopsignals bei Honigbienen: zeitliche Verteilung und Einfluss eines Gedränges am Futterplatz. Vibrationssignale spielen eine wichtige Rolle bei der Kommunikation von sozialen Insekten. Allerdings wissen wir bisher wenig über Signale, die für eine negative Rückkopplungen sorgen bzw. die Aktivitäten des Bienenvolkes verringern oder verändern. Wir untersuchten daher das Stopsignal der Honigbienen, ein kurzes pulsierendes Vibrationssignal, das innerhalb des Bienenstockes 
von Sammelbienen erzeugt wird. Stopsignale können die Rekrutierung weiterer Sammlerinnen verringern, wenn tanzende Bienen aufgrund überfüllter Futterplätze ihren Schwänzeltanz beenden. Damit könnte dieses Verhalten bei der Regulation der Sammeltätigkeit eine Rolle spielen. Trotzdem wissen wir nach wie vor nicht, ob die Bienen während ihres Aufenthaltes im Stock das Stopsignal durch eine Veränderung der Frequenz oder aber durch andere Parameter erzeugen. Die bisherigen Untersuchungen zu dieser Frage haben überfüllte Futterstellen verwendet, um die Abgabe von Stopsignalen bei den Bienen zu stimulieren.

Wir richteten unser Hauptaugenmerk auf individuelle Sammelbienen und stellten fest, dass auch Bienen, die von nicht überfüllten Futterplätzen zurückkehrten, Stopsignale abgaben. Diese Sammlerinnen produzierten mehr Stopsignale, wenn sie längere Zeit im Stock verbrachten und reduzierten dabei signifikant die Häufigkeit der Signalabgabe während ihres Aufenthaltes im Stock. Diese Reduzierung könnte dadurch zustande kommen, dass die Motivation der Bienen zur Signalabgabe bei zunehmender Aufenthaltsdauer im Stock abnimmt. Gleichzeitig nimmt während des Aufenthaltes einer signalgebenden Biene im Stock die Pulsdauer des Signals tendenziell zu, während die Grundfrequenz leicht abnimmt.

Wir untersuchten darüber hinaus, welchen Einfluss ein Gedränge am Futterplatz hat. Dazu dressierten wir 20 Sammelbienen zu einer Futterquelle und beobachteten das Verhalten dieser Sammelbienen bevor und nachdem wir die Anzahl der Futterstellen reduziert hatten. Dadurch erhöhten wir die Wartezeit bei der Fütterung von 0 auf 409,4 $\pm 264,3$ s, ohne dabei den Nektareintrag des Bienenvolkes signifikant $\mathrm{zu}$ verändern (es gab keine Veränderung bei der Wartezeit der Sammlerinnen für die Nektarabgabe). Diese Versuchsanordnung bewirkte keine Änderungen in der Signalproduktion durch die Testbienen selbst; jedoch wurde die Anzahl der Stopsignale, die diese Testbienen innerhalb des Stockes erhielten, verdoppelt. Mindestens $38 \%$ dieser Signale wurden von Sammlerinnen abgegeben, die dieselbe Futterquelle besucht hatten und dabei möglicherweise erfolglos waren.

Das Stopsignal könnte eine modulierende Rolle spielen und daher auch dann auf einem „Baseline“Niveau vorhanden sein, wenn es wie in unserem ersten Versuch mit nicht überfüllten Futterplätzen keine Notwendigkeit gibt, die Sammeltätigkeit $\mathrm{zu}$ begrenzen. Modulierende Signale werden in sehr unterschiedlichen Zusammenhängen produziert und zeichnen sich dadurch aus, dass sie die Wahrscheinlichkeit für ein bestimmtes Verhalten beim Signalempfänger in Abhängigkeit von dessen Reaktionsschwelle verändern (Hölldobler, 1999). Wir vermuten daher, dass in Abhängigkeit von der Reaktionsschwelle des Empfängers Stopsignale so lange keinen Effekt auf der Ebene des Bienenvolkes ausüben, bis der Signallevel erhöht worden ist.
Ein Effekt auf der Bienenvolkebene (wie z. B. die Verdoppelung der Signale für unsere Testbienen) würde dann entstehen, wenn viele Bienen unabhängig voneinander über die Bedingungen an einer bestimmten Futterquelle Signale abgeben und Informationen erhalten; dadurch wird möglicherweise auch die Genauigkeit des Informationsaustausches erhöht.

\section{Stopsignal/ kurzes Pipingsignal/Sammeln/ nega- tive Rückkopplung}

\section{REFERENCES}

Bonabeau E., Dorigo M., Theraulaz G. (1999) Swarm intelligence: from natural to artificial systems, Oxford University Press, New York.

Bradbury J., Vehrencamp S.L. (1998) Principles of animal communication. Sinauer Associates, Inc., Sunderland, Massachusetts.

Couvillon M.J., Robinson E.J.H., Atkinson B., Child L.,Dent K.R., Ratnieks F.L.W. (2008) En garde: rapid shifts in honeybee, Apis mellifera, guarding behaviour are triggered by onslaught of conspecific intruders, Anim. Behav. 76, 1653-1658.

Esch H.E. (1964) Beiträge zum Problem der Entfernungsweisung in den Schwänzeltanzen der Honigbiene, Z. Vergl. Physiol. 48, 534-546.

Ewing A.W. (1989) Arthropod bioacoustics: neurobiology and behavior, Comstock Publishing Associates, Ithaca, New York.

Farina W.M., Wainselboim A.J. (2001) Thermographic recordings show that honeybees may receive nectar from foragers even during short trophallactic contacts, Insect. Soc. 48, 360-362.

Hölldobler B. (1999) Multimodal signals in ant communication, J. Comp. Physiol. A 184, 129-141.

Hölldobler B., Wilson E.O. (1990) The ants. Belknap Press of Harvard University Press, Cambridge, Massachusetts.

Hrncir M., Schmidt V.M., Schorkopf D.L., Jarau S., Zucchi R., Barth F.G. (2006) Vibrating the food receivers: a direct way of signal transmission in stingless bees (Melipona seminigra), J. Comp. Physiol. A 192, 879-887.

Kirchner W.H. (1993) Vibrational signals in the tremble dance of the honeybee, Apis mellifera, Behav. Ecol. Sociobiol. 33, 169-172.

Michelsen A., Kirchner W.H., Lindauer M. (1986) Sound and vibrational signals in the dance language of the honeybee, Apis mellifera, Behav. Ecol. Sociobiol. 18, 207-212.

Nieh J.C. (1993) The stop-signal of honey bees: reconsidering its message, Behav. Ecol. Sociobiol. 33, $51-56$. 
Pastor K.A., Seeley T.D. (2005) The brief piping signal of the honey bee: begging call or stop-signal? Ethology 111, 775-784.

Renner M., Nieh J.C. (2008) Bumble bee olfactory information flow and contact-based foraging activation, Insect. Soc. 55, 417-424.

Roces F., Tautz J., Hölldobler, B. (1993) Stridulation in leaf-cutting ants, Naturwissenschaften 80, 521524.

Schneider S.S., Lewis L.A. (2004) The vibration signal, modulatory communication and the organization of labor in honey bees, Apis mellifera, Apidologie 35, 117-131.

Schneider S.S., Stamps J.A., Gary N.E. (1986) The vibration dance of the honey bee. 1. Communication regulating foraging on two time scales, Anim. Behav. 34, 377-385.

Seeley T.D. (1985) Honeybee ecology, Princeton University Press, Princeton, NJ.

Seeley T.D. (1992) The tremble dance of the honey bee: Message and meanings, Behav. Ecol. Sociobiol. 31, 375-383.

Seeley T.D., Tautz J. (2001) Worker piping in honey bee swarms and its role in preparing for liftoff, $\mathrm{J}$. Comp. Physiol. A 187, 667-676.
Seeley T.D., Weidenmuller A., Kuhnholz S. (1998) The shaking signal of the honey bee informs workers to prepare for greater activity, Ethology 104, 10-26.

Stabentheiner A. (1996) Effect of foraging distance on the thermal behaviour of honeybees during dancing, walking and trophallaxis, Ethology 102, 360370 .

Stabentheiner A., Kovac H., Hagmuller K. (1995) Thermal behavior of round and wagtail dancing honeybees, J. Comp. Physiol. B 165, 433-444.

Thom C. (2003) The tremble dance of honey bees can be caused by hive-external foraging experience, $\mathrm{J}$. Exp. Biol. 206, 2111-2116.

Thom C., Gilley D.C., Tautz J. (2003) Worker piping in honey bees (Apis mellifera): the behavior of piping nectar foragers, Behav. Ecol. Sociobiol. 53, 199205.

von Frisch K. (1946) Die Tänze der Bienen, Österr. Zoolog. Zeitschr. 1, 1-48.

von Frisch K. (1967) The dance language and orientation of bees, 2nd printing, 1993 edn. Belknap Press, Cambridge, Massachusetts.

Winston M.L. (1987) The biology of the honey bee. Harvard University Press, Cambridge, Massachusetts. 